\title{
Heavy Metals in Wheat Grown in Sewage Irrigation: A Distribution and Prediction Model
}

\author{
Xiaoman Yu' ${ }^{1,6}$, Zuwei Wang'*, Alexandra Lynn ${ }^{3}$, Jianchao Cai ${ }^{4}$, \\ Yanchong Huangfu ${ }^{3}$, Yong Geng ${ }^{1}$, Jiaxi Tang ${ }^{5}$, Xiangfeng Zeng ${ }^{1 * *}$
}

\author{
${ }^{1}$ Key Laboratory of Pollution Ecology and Environmental Engineering, Institute of Applied Ecology, \\ Chinese Academy of Sciences, \\ Shenyang 110016, China \\ ${ }^{2}$ Tianjin Key Laboratory of Water Resource and Water Environment, Tianjin Normal University, \\ Tianjin 300387, China \\ ${ }^{3}$ Center for Environmental Biotechnology, The University of Tennessee, \\ Knoxville, 37996, USA \\ ${ }^{4}$ Institute of Geophysics and Geomatics, China University of Geosciences, \\ Wuhan 430074, P.R. China \\ ${ }^{5}$ College of Environmental Science and Engineering, Liaoning Technical University, \\ Fuxin 123000, China \\ ${ }^{6}$ University of Chinese Academy of Sciences, Beijing 100039, China
}

Received: 27 July 2015

Accepted: 24 October 2015

\begin{abstract}
The distribution of and prediction models for heavy metals in wheat were evaluated in Tianjin, China. The results indicated that there were high heavy metal concentrations $(\mathrm{Zn}, \mathrm{Cd}, \mathrm{Cu}, \mathrm{Pb}, \mathrm{Cr}$, and $\mathrm{Ni}$ ) in the wheat and that the $\mathrm{Cd}$ concentration $(0.062 \mathrm{mg} \cdot \mathrm{kg}-1)$ in the seeds actually exceeded the national safety standard. The accumulation factors for the wheat's seeds were of a decreasing order: $\mathrm{Zn}>\mathrm{Cd}>\mathrm{Cu}>\mathrm{Pb}>\mathrm{Cr}>\mathrm{Ni}$. The $\mathrm{Cd}$ concentration in the wheat's seeds corresponded closely with the Cd concentration in the soil $(\mathrm{r}=0.74)$. The predicting model was appropriate for predicting the concentration of $\mathrm{Cd}$ and $\mathrm{Zn}$ in wheat, and the $\mathrm{r}$ was 0.735 and 0.625 , respectively.
\end{abstract}

Keywords: wheat, heavy metal, prediction model, soil properties, sewage irrigation

\section{Introduction}

As economies develop, water shortages have become a significant limiting factor of local economic development and of people's daily lives [1]. Therefore, during arid

*e-mail: shidalvwo@126.com

**e-mail: xf6.zeng@gmail.com seasons, sewage has become a major water source for irrigation in cities, towns and other areas [2]. However, this unsuitable wastewater irrigation introduces a series of environmental issues [3, 4]. Because of a drought in Northern China, the people located upstream of the Haihe River Valley built many dams and reservoirs, which caused the water yield flowing into Tianjin to decrease, and consequently lead to a water shortage for 
Tianjin's agricultural and industrial fields. Meanwhile, an abundance of untreated, industrial wastewater was discharged into Bohai Sea through the new Yongding River and the Beijing Pollution Discharging River. This sewage has become a new means of compensating for the water shortages in the Tianjin agriculture industry and thus, has formed a wastewater irrigation region that has lasted for several decades [5, 6].

Although irrigating with wastewater circumvents water shortages in agriculture, it also allows for a large number of organic pollutants and poisonous heavy metal elements to leach into the soil and pollute its surroundings, which can be detrimental for people through the food chain [1, 7]. Hence, analyzing wastewater-irrigated soil is useful for determining the environmental quality of a crop system. Numerous studies have previously investigated the organic pollution and heavy metal pollution of crops [3, $8,9]$, for exampe, the soil and vegetables of a marshy field in the wastewater irrigation region of Tianjin. However, very few studies have been done on the heavy metal pollution of wheat, and likewie, there is no information on a prediction model for wastewater-irrigated wheat in Tianjin. The objectives of this study were (1) evaluate the heavy metal pollution in wheat grown in the wastewater irrigating region in Tianjin, (2) analyze the correlations between the heavy metal concentration in wheat and relevant factors, and (3) construct a prediction model for the heavy metal concentration in wheat.

\section{Materials and Methos}

\section{Study Area}

Tianjin, located at coordinates $39^{\circ} 08^{\prime} \mathrm{N} 117^{\circ} 11^{\prime} \mathrm{E}$, lies in the northeast part of the North China Plain, in front of Yanshan and west of Bohai. It is becoming the economic center of Northern China as well as one of China's biggest coastal cities. The area's wastewater irrigating region is distributed throughout the plain's low lying areas, and

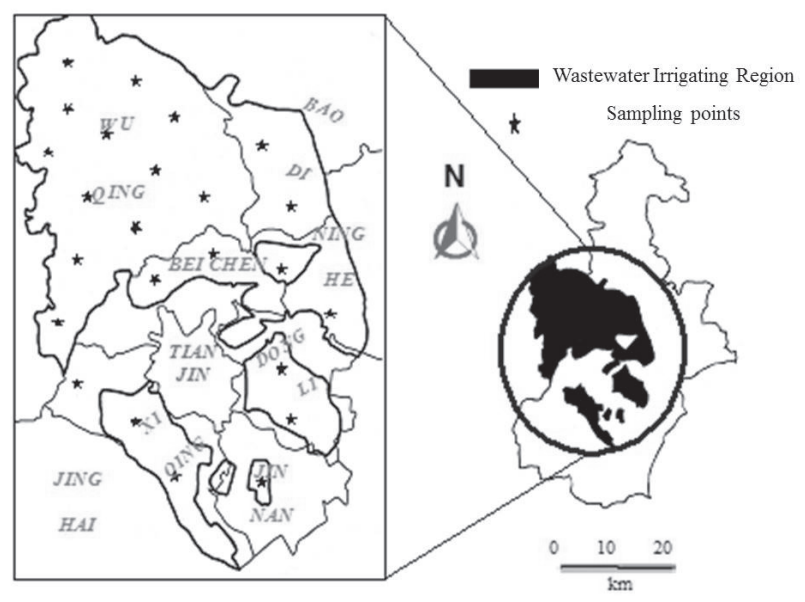

Fig.1. Location map of the study area with sampling points. the soil is nurtured on fourth century deposited sediment, which is a moisture-rich soil with a simple matrix. The main part of the land is modern alluvial soil from a river, and the rest is deluvial material and marine feces. The wastewater irrigating region's climate in Tianjin is an extratropical semi-humid monsoonal continental climate, which brings drought in the spring but waterlogging in the fall. The average annual precipitation is about 557 millimeters, and the lowest precipitation is 271.1 millimeters. $60 \%$ of the total rainfall in a year is concentrated in July and August. The total rainfall from March to May is only $12 \%$ of the total rainfall in a year, and the rainfall in winter is only $3 \%$ of the total rainfall in a year. Therefore, during the Agro-irrigation seasons in the spring and winter, the water requirement is very high. Because Tianjin lacks fresh water, it is necessary for the municipal sewage to compensate by serving as an additional water resource for irrigation use in agriculture [10].

\section{Sampling Strategy}

According to the principles of representativeness, typicalnes, and timeliness, and in conjunction with different administrative divisions, soil types, the physicochemical properties of soil, and the intensity and dimensions of the sewage irrigation, certain plots were arranged under the grid method. They were located in wheatabundant farmland in seven districts (Xiqing, Dongli, Jinnan, Beichen, Ninghe, Baodi, and Wuqing). The arranged plots dimensions were roughly $10 \times 10 \mathrm{~km}$, and there were a total of 24 sampling points. (Fig. 1).

Representative samples of soil and wheat that were ready for harvest were collected in the divided sampling plots and according to the cinquefoil five-point sampling method. Each wheat sample included the root and stem leaf, and seed was collected at the same time. At the same time, related soil samples were taken with a $5 \mathrm{~cm}$ diameter stainless steel auger at the $0-15 \mathrm{~cm}$ layer, homogenized in plastic bags, and stored at $4^{\circ} \mathrm{C}$

In a laboratory, the wheat samples were thoroughly washed by flushing with tap water to remove airborne dust and soil particles and then submerged in deionized water to remove the tap water. The root, stem leaf, and seeds of the wheat samples were separated, dried at $55-60^{\circ} \mathrm{C}$, and pulverized to pass through a 40 -mesh sieve. The soil samples were air-dried and then passed through a 60-mesh sieve. Sub-samples of soil were used to measure the physico-chemical properties according to standard procedure.

\section{Analytical Methods}

The main characteristics detected in the soil were $\mathrm{pH}$, the abundance of organic matter total salt, the heavy metals (Cd, $\mathrm{Cu}, \mathrm{Pb}, \mathrm{Zn}, \mathrm{Cr}$, and $\mathrm{Ni}$ ).

The $\mathrm{HNO}_{3}-\mathrm{HClO}_{4}-\mathrm{HF}$ three-acid-digestion method was used in the soil heavy metal gross analysis, and we also incorporated ICP-AES PDP spectroscopic methodology in our analysis $[10,11]$. Plant samples were digested with a 
treatment of $\mathrm{HClO}_{4}$ and $\mathrm{HNO}_{3}$ and were then analyzed by an ICP-MS inductive coupling PDP mass spectrograph [3].

The other soil properties, including the organic matter, available phosphorus, available potassium, and $\mathrm{pH}$, were analyzed by using corresponding methods. Soil $\mathrm{pH}$ was measured in 1:2.5 (m/V) soil: water using an electronic $\mathrm{pH}$ meter (PB-10, Sartorius, China). Soil organic matter was determined by the $\mathrm{K}_{2} \mathrm{Cr}_{2} \mathrm{O}_{7}-\mathrm{H}_{2} \mathrm{SO}_{4}$ oxidation method. The total salt concentration in the soil was measured by a weighting method [12].

\section{Transfer Factor}

The heavy metal concentrations in the soil and plant extracts were calculated on the basis of dry weight. The plant concentration factor (PCF) was calculated as follows:

$$
\mathrm{PCF}=\mathrm{C}_{\text {plant }} / \mathrm{C}_{\text {soil }}
$$

... where $\mathrm{C}_{\text {plant }}$ and $\mathrm{C}_{\text {soil }}$ represent the heavy metal concentration in the extracted plant and soil samples on a dry weight basis, respectively.

\section{Results and Discussion}

\section{Distributional Characteristics of Heavy Metals in Wheat}

The water-irrigated wheat roots, stem leaves, and seeds had different absorption capabilities in addition to different heavy metals (Table 1).

The average $\mathrm{Cd}$ concentration varied among the different wheat parts as well as de-creased in the following order: $\operatorname{root}>$ stem leaf $>$ seed. The $\mathrm{Cd}$ concentration in the root was 2.73 and 3.51 times higher than that in the seeds and stem leaf, respectively. However, there was not a dramatic variation between the $\mathrm{Cd}$ concentrations present in the stem leaf and the seeds. The average $\mathrm{Cd}$ concentration in the seeds surpassed the set tolerance limit of Cd in foods (GB15201-1994, $0.05 \mathrm{mg} \cdot \mathrm{kg}^{-1}$ ), meaning that the wheat had been polluted by $\mathrm{Cd}$. The average concentrations in the wheat of $\mathrm{Cu}, \mathrm{Pb}, \mathrm{Zn}$, and $\mathrm{Cr}$ had a similar distribution, but they did not surpass their food tolerance limits. The heavy metal uptake by the wheat roots was in the following order: $\mathrm{Zn}>\mathrm{Cu}>\mathrm{Ni}>\mathrm{Pb}>\mathrm{Cr}>\mathrm{Cd}$, which is in contrast to the stem leaves and seeds, where they were $\mathrm{Zn}>\mathrm{Cu}>\mathrm{Ni}>\mathrm{Cr}>\mathrm{Pb}>\mathrm{Cd}$ and $\mathrm{Zn}>\mathrm{Cu}>\mathrm{Cr}>\mathrm{Ni}>\mathrm{Pb}>\mathrm{Cd}$, respectively.

From among these six heavy metal elements, every element was present in its highest concentration in the wheat roots, illustrating that the roots have the strongest heavy metal uptake capability. The plants absorb elements from the surrounding soil, so therefore the elements first accumulate in the root. Then some of the elements transport to other parts of the plants. Thus, different plant parts have different accumulation capabilities for metal elements. However, for the majority of cases, the underground parts typically accumulate more than those that are above ground [6]. Passage from the ex planta to in planta regions of the soil-plant system is dependent not only on the plant's properties but also on the heavy metal pollutant's properties [14]. Comparing the concentrations present in the stem leaf with those in the seeds, the $\mathrm{Pb}, \mathrm{Cr}$, and $\mathrm{Ni}$ concentrations in the stem leaf are significantly higher than those in the seeds. However, for $\mathrm{Cd}$ its concentration in the stem leaf is also higher than that in the seeds, but the concentration difference between the two locations is not nearly as obvious.

In sharp contrast, the $\mathrm{Zn}$ concentration in the stem leaf is significantly lower than that in the seeds. Finally, although the $\mathrm{Cu}$ concentration in the stem leaf is also lower than that in the seeds, the difference is not as significant

Table 1 . Concentrations of heavy metals in wheat $\left(\mathrm{mg} \cdot \mathrm{kg}^{-1}\right)$.

\begin{tabular}{|c|c|c|c|c|c|c|c|}
\hline \multicolumn{2}{|c|}{ Elements } & $\mathrm{Cd}$ & $\mathrm{Cu}$ & $\mathrm{Pb}$ & $\mathrm{Zn}$ & $\mathrm{Cr}$ & $\mathrm{Ni}$ \\
\hline \multirow{4}{*}{$\begin{array}{c}\text { seed } \\
(n=24)\end{array}$} & Range value & $0.025-0.117$ & $2.1-4.16$ & $0.0-0.24$ & $16 .-52.95$ & $0.2-0.62$ & $0-0.52$ \\
\hline & Mean value & 0.062 & 2.99 & 0.14 & 27.67 & 0.49 & 0.29 \\
\hline & Standard deviation & 0.020 & 0.51 & 0.05 & 7.33 & 0.10 & 0.14 \\
\hline & CV (\%) & 31.48 & 16.98 & 34.58 & 26.49 & 20.69 & 47.35 \\
\hline \multirow{4}{*}{$\begin{array}{c}\text { Stem leaf } \\
(\mathrm{n}=24)\end{array}$} & Range value & $0.027-0.146$ & $1.74-4.13$ & $0.05-0.69$ & $5.28-22.46$ & 0.2900 .95 & $0.37-0.41$ \\
\hline & Mean value & 0.080 & 2.70 & 0.45 & 11.87 & 0.69 & 0.80 \\
\hline & Standard deviation & 0.029 & 0.58 & 0.17 & 4.59 & 0.16 & 0.31 \\
\hline & CV $(\%)$ & 35.40 & 21.47 & 37.95 & 38.68 & 23.30 & 38.86 \\
\hline \multirow{4}{*}{$\begin{array}{c}\text { root } \\
(n=24)\end{array}$} & Range value & $0.078-0.517$ & $3.11-9.50$ & $0.37-2.54$ & $19.73-63.62$ & $0.93-4.35$ & $2.96-7.98$ \\
\hline & Mean value & 0.218 & 5.84 & 1.26 & 39.51 & 3.02 & 5.54 \\
\hline & Standard deviation & 0.108 & 1.51 & 0.62 & 10.43 & 0.98 & 1.49 \\
\hline & CV (\%) & 49.35 & 25.87 & 48.74 & 26.40 & 32.40 & 26.85 \\
\hline
\end{tabular}

Note: CV means coefficient of variability 
Table 2. Concentrations of heavy metals in soils.

\begin{tabular}{|c|c|c|c|c|c|c|}
\hline Element & $\mathrm{Cd}$ & $\mathrm{Cu}$ & $\mathrm{Pb}$ & $\mathrm{Zn}$ & $\mathrm{Cr}$ & $\mathrm{Ni}$ \\
\hline Ranges $\left(\mathrm{mg} \cdot \mathrm{kg}^{-1}\right)$ & $0.05-1.17$ & $10.92-61.32$ & $3.8-49.79$ & $62.22-333.6$ & $40.16-108$ & 15.91-61.42 \\
\hline Mean values $\left(\mathrm{mg} \cdot \mathrm{kg}^{-1}\right)$ & 0.46 & 28.15 & 15.62 & 129.08 & 64.19 & 32.08 \\
\hline Standard deviation & 22.29 & 9.45 & 6.34 & 56.23 & 12.25 & 7.42 \\
\hline Dissociation Modulus (\%) & 48 & 33.58 & 40.57 & 43.57 & 19.09 & 23.14 \\
\hline $\begin{array}{l}\text { Environmental quality standard of soils } \\
\text { (background) }\end{array}$ & 0.20 & 35 & 35 & 100 & 90 & 40 \\
\hline $\begin{array}{l}\text { Environmental quality standard of soils } \\
\text { (secondary) }\end{array}$ & 0.30 & 100 & 300 & 250 & 300 & 50 \\
\hline
\end{tabular}

as that exhibited by the $\mathrm{Zn}$ concentration. The six heavy metals examined in this research have different chemical properties and, consequently, each metal has distinct accumulation and translocation capacities.

The Analysis of Influence Factors

The transfer and transformation mechanisms for heavy metals in the soil-plant system are complicated and influenced by multiple factors. Numerous studies have demonstrated that a number of factors affect heavy metals bioavailability in soils, including soil $\mathrm{pH}$, organic matter (OM), cation exchange capacity (CEC), cultivars of crop plants, plant age, and so on. Theses pre-existing reports make it clear that heavy metal bioavailability in the soil is closely linked to the soil's heavy metal concentration, $\mathrm{pH}$ value, organic matter, total salt, and soil type [15].

The heavy metal concentrations present in the surface soil are detailed in Table 2. The Cd concentration in the soil surpassed the secondary stadard environmental quality standard for soils (GB15618-1995), which demonstrated that the soil was polluted by $\mathrm{Cd}$. The $\mathrm{Zn}$ and $\mathrm{Ni}$ concentrations in the soil ranged from 62.22 to $333.6 \mathrm{mg} \cdot \mathrm{kg}^{-1}$ and 15.91 to $61.42 \mathrm{mg} \cdot \mathrm{kg}^{-1}$, respectively, and more than half of the sampling points contained $\mathrm{Zn}$ concentrations that surpassed the secondary stadard environmental quality standard for soils (GB15618-1995). $\mathrm{The} \mathrm{Pb}, \mathrm{Cu}$, and $\mathrm{Cr}$ concentrations were in the background value. The relationship between the total heavy metal concentrations in the seeds of the 24 monitored plant samples and the relevant soil samples were analyzed. The correlation factors of $\mathrm{Cd}, \mathrm{Pb}, \mathrm{Zn}, \mathrm{Cr}, \mathrm{Ni}$, and $\mathrm{Cu}$ in the seeds were $0.4463,0.4094,0.2640,0.3616,02142$, and 0.1565 , respectively. The correlation factors of $\mathrm{Cd}$ and $\mathrm{Pb}$ were higher than any of the other four elements, meaning that their concentrations in the seeds had already been greatly affected by the heavy metal concentrations present in the soil.

From among the previously mentioned soil properties, $\mathrm{pH}$ plays the most important role in determining metal speciation due to its strong effect on the solubility and speciation of metals in the soil and solution [16]. Dramatic increases in heavy metals desorption from the soil constituents and its dissolution ability in solution have been observed with a corresponding decrease in soil $\mathrm{pH}$
$[17,18]$. The bioavailability of heavy metals in soil also increases when the soil $\mathrm{pH}$ decreases. The $\mathrm{pH}$ for the soil in the wastewater irrigating region of Tianjin ranged from 7.8 to 8.3 , and the soils all showed alkalescency (Table 3 ). The correlation factors of the presence of $\mathrm{Cd}, \mathrm{Pb}, \mathrm{Zn}, \mathrm{Cr}$, $\mathrm{Ni}$, and $\mathrm{Cu}$ in the seeds with $\mathrm{pH}$ were $-0.0154,-0.0502$, $-0.3714,-0.1389,-0.3215$, and -0.1758 , respectively (Fig. 2). The $\mathrm{Zn}$ and Ni correlation factors were higher than any of the other four elements, meaning that their concentrations in the seed had been greatly affected by $\mathrm{pH}$.

Apart from soil $\mathrm{pH}$, the soil's $\mathrm{OM}$ is another important factor that affects heavy metal availability [19, 20]. It has been reported that heavy metal adsorption onto soil constituents declines when the soil's organic matter content decreases, and conversely when the soil's organic matter increases, the plant's ability to uptake heavy metals decreases $[6,21]$. The organic matter of the soil in the wastewater irrigating region of Tianjin ranged from $1.3 \%$ to $1.8 \%$ (Table 3 ). The correlation factors of the presence of $\mathrm{Cd}, \mathrm{Cu}, \mathrm{Pb}, \mathrm{Zn}, \mathrm{Cr}$, and $\mathrm{Ni}$ in the seeds with $\mathrm{pH}$ were $-0.2819,-0.6032,-0.2375,-0.0419,-0.0995$, and -0.016 , respectively (Fig. 2). The $\mathrm{Cu}$ correlation factor was higher than for any of the other elements, meaning that the $\mathrm{Cu}$ concentration in the seeds had been greatly affected by the soil's organic matter.

The salt concentration of the soil in the wastewater irrigating region of Tianjin ranged from $0.041 \%$ to $0.052 \%$, and the soils were of the classification of mild and moderate salinity (Table 3 ). The correlation factors of the presence of $\mathrm{Cd}, \mathrm{Cu}, \mathrm{Pb}, \mathrm{Zn}, \mathrm{Cr}$, and $\mathrm{Ni}$ in the seeds with $\mathrm{pH}$ were $-0.0254,-0.1430,0.0389,0.2912,-0.2412$, and 0.0070 , respectively (Fig. 2). The correlation factors of all the heavy metals were low, meaning that their concentrations in the seeds had not been affected by the soil's salt concentration. In different types of soil, heavy metals have different bioavailability $[22,23]$. The PCF of $\mathrm{Cd}$ in wheat was arranged in the following order: chiltern moisture soil $>$ loam moisture soil $>$ ordinary moisture soil $>$ viscidity moisture soil (Fig. 3 ). The PCF of heavy metals in wheat was highest in the loam moisture soil, meaning that heavy metals in the loam moisture soil had high bioavailability, and the PCF of Zn was higher than for any of the other five heavy metals. 
Table 3. The physicochemical properties of soil $(n=24)$.

\begin{tabular}{|c|c|c|c|c|}
\hline Mean value & Chiltern moisture soil & Loam moisture soil & Viscidity moisture soil & Ordinary moisture soil \\
\hline Organic matter \% & 1.3011 & 1.6351 & 1.8025 & 1.5350 \\
\hline The salt concentration \% & 0.0411 & 0.0508 & 0.0517 & 0.0471 \\
\hline PH value & 7.8667 & 7.7833 & 8.3010 & 7.8801 \\
\hline
\end{tabular}

\section{Prediction Model for Heavy Metals in Wheat}

The ability of differing soil factors from various soil types to influence plants' uptake of heavy metals as well as the difficulties in assessing the existence of heavy metals in complex soil types have encouraged the development of prediction models capable of predicting trace element transfers to plants [24]. The model provides a great opportunity to carry out ecological risk assessments and establish soil quality criteria for heavy metals. However, diverse soil factor influences may result in avariability of ecological risk assessments in different soils and of the soil quality criteria for heavy metals. The heavy metal concentration in wheat is influenced by the heavy metal concentrations in the soil, $\mathrm{pH}$, organic matter, total salt concentration, and type of soil. The quantification theory to forecast was used to develop this model. The predicting model for heavy metals in wheat was constructed following the method described by Hakanson and Zheng $[25,26]$.

The forecasting formulas of the acquisition of heavy metal in wheat are listed in the following:

$$
\begin{array}{ll}
- & \mathrm{Y}_{\mathrm{Cd}}=-0.0167 \mathrm{X}_{1 \mathrm{Cd}}+0.0115 \mathrm{X}_{2}+0.5217 \mathrm{X}_{3}+0.0432 \mathrm{X}_{4}- \\
& 0.3097 \mathrm{X}_{5}-0.3252 \mathrm{X}_{6}-0.3111 \mathrm{X}_{7}(\mathrm{r}=0.7349) \\
- & \mathrm{Y}_{\mathrm{Cu}}=-0.0164 \mathrm{X}_{1 \mathrm{Cu}}+0.2474 \mathrm{X}_{2}+9.8533 \mathrm{X}_{3}+0.3014 \mathrm{X}_{4} \\
& -0.0683 \mathrm{X}_{5}+0.2302 \mathrm{X}_{6}+0.2795 \mathrm{X}_{7}(\mathrm{r}=0.4197) \\
& \\
- & \mathrm{Y}_{\mathrm{Pb}}=0.0086 \mathrm{X}_{1 \mathrm{~Pb}}-0.029 \mathrm{X}_{2}+0.7788 \mathrm{X}_{3}+0.038 \mathrm{X}_{4} \\
& -0.2612 \mathrm{X}_{5}-0.2706 \mathrm{X}_{6}-0.278 \mathrm{X}_{7}(\mathrm{r}=0.5341) \\
& \\
- & \mathrm{Y}_{\mathrm{Zn}}=0.0301 \mathrm{X}_{1 \mathrm{Zn}}-3.57 \mathrm{X}_{2}+40.705 \mathrm{X}_{3}-7.799 \mathrm{X} 4 \\
& +85.7536 \mathrm{X}_{5}+84.8755 \mathrm{X}_{6}+92.3341 \mathrm{X}_{7}(\mathrm{r}=0.6250)
\end{array}
$$

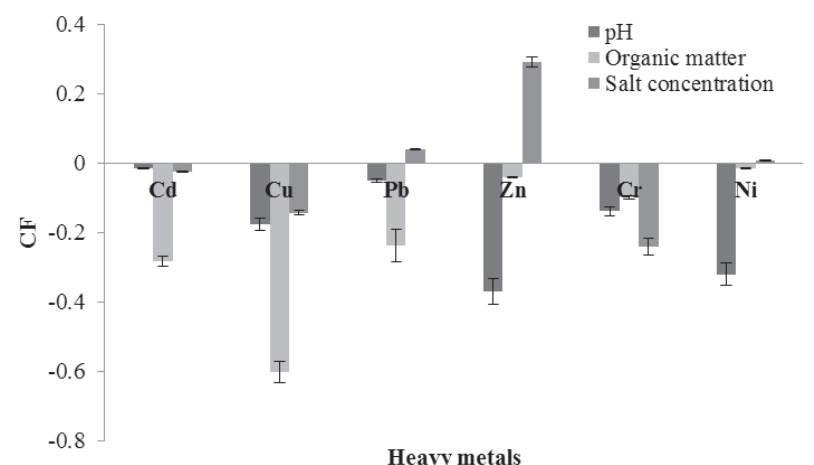

Fig. 2. The correlation between the concentration factor for heavy metals in wheat and the physicochemical properties of soil.

$$
\begin{gathered}
-\mathrm{Y}_{\mathrm{Cr}}=0.004 \mathrm{X}_{1 \mathrm{Cr}}+0.0283 \mathrm{X}_{2}-0.2597 \mathrm{X}_{3}-0.0392 \mathrm{X}_{4} \\
+0.5459 \mathrm{X}_{5}+0.5279 \mathrm{X}_{6}+0.54 \mathrm{X}_{7} \quad(\mathrm{r}=0.3992) \\
-\mathrm{Y}_{\mathrm{Ni}}=-0.0004 \mathrm{X}_{1 \mathrm{Ni}}-1.1045 \mathrm{X}_{2}-0.0659 \mathrm{X}_{3}-0.0238 \mathrm{X}_{4} \\
-0.8159 \mathrm{X}_{5} \mathrm{v} .0213 \mathrm{X}_{6}-0.9322 \mathrm{X}_{7} \quad(\mathrm{r}=0.5523)
\end{gathered}
$$

...where $\mathrm{Y}$ is the heavy metal concentration in wheat, $\mathrm{X}_{1}$ is the full dose of heavy metal in soil, $X_{2}$ is soil $\mathrm{pH}, \mathrm{X}_{3}$ is the soil's organic matter, $\mathrm{X}_{4}$ is the total salt concentration in the soil, $\mathrm{X}_{5}$ is the chiltern moisture soil, $\mathrm{X}_{6}$ is loam soil, and $\mathrm{X}_{7}$ is gloea moisture soil.

The multiple correlation factor $r$ was used to measure the forecasting accuracy of the fore-casting model. The correlation factor $\mathrm{r}$ of $\mathrm{Cd}$ and $\mathrm{Zn}$ was 0.7349 and 0.6250 , respectively. They were higher than the correlation factor $\mathrm{r}$ of $\mathrm{Ni}, \mathrm{Pb}, \mathrm{Cu}$, and $\mathrm{Cr}$, meaning that the predicting model was appropriate for predicting the $\mathrm{Cd}$ and $\mathrm{Zn}$ concentrations in wheat.

\section{Conclusion}

The heavy metal concentrations $(\mathrm{Zn}, \mathrm{Cd}, \mathrm{Cu}$, $\mathrm{Pb}, \mathrm{Cr}$, and $\mathrm{Ni}$ ) in wheat that had been irrigated with wastewater in Tianjin were high, and the Cd concentration $\left(0.062 \mathrm{mg} \cdot \mathrm{kg}^{-1}\right)$ in seeds actually exceeded the national safety standard. Differing parts of the wheat plant had different accumulation abilities, and the accumulation factor of the wheat's seeds followed a decreasing order of $\mathrm{Zn}>\mathrm{Cu}>\mathrm{Cr}>\mathrm{Ni}>\mathrm{Pb}>\mathrm{Cd}$. The heavy metal distribution in wheat was entirely affected by the heavy metal concentrations in the soil, $\mathrm{pH}$ value, organic matter, total

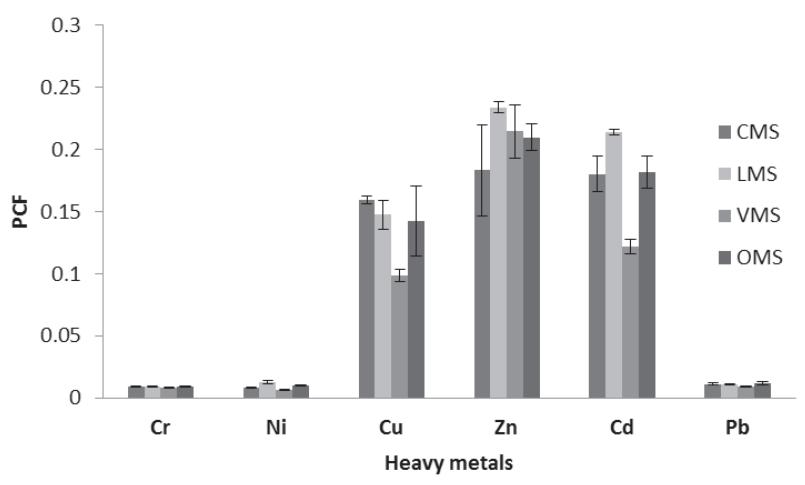

Fig. 3. The concentration factor for heavy metal in wheat in different types of soils. 
salt, and soil texture. The $\mathrm{Cd}$ and $\mathrm{Pb}$ correlation factors were higher than for any of the other four elements, meaning that their concentrations in the seeds had been greatly affected by the heavy metal concentration in the soil. The $\mathrm{Zn}$ and Ni concentrations in the seeds were largely impacted by the $\mathrm{pH}$ value, whereas the $\mathrm{Cu}$ concentration in the seeds was greatly affected by the soil's organic matter. Additionally, the heavy metals present in the loam moisture soil had a high bioavailability. Finally, the predicting model was appropriate for predicting the concentrations of $\mathrm{Cd}$ and $\mathrm{Zn}$ in wheat, and $\mathrm{r}$ was 0.7349 and 0.6250 , respectively.

\section{Acknowledgements}

This research was funded by the National Nature Science Foundation of China (Nos.: 415548 and; 40973078). We thank reviewers for their valuable and constructive comments.

\section{References}

1. LUY., SONG S., WANG R., LIU Z., MENG J., SWEETMEN, A., JENKINS A., FEERIER R., LI H., LUO W., WANG T. Impacts of soil and water pollution on food safety and health risks in China. Environ Int. 77, 5, 2015.

2. DING C., ZHANG T., WANG X., ZHOU F., YANG Y., YING $Y$. Effects of soil type and genotype on lead concentration in rootstalk vegetables and the selection of cultivars for food safety. J Environ Manage. 122, 8, 2013.

3. KKAN S., AIJUN L., ZHANG S., HU Q., ZHU Y. Accumulation of polycyclic aromatic hydrocarbons and heavy metals in lettuce grown in the soils contaminated with long-term wastewater irrigation. J Hazard Mater. 152, 506, 2008.

4. ZHAO Q., WANG Y., CAO Y., CHEN A., REN M., GE Y., LI L. Potential health risks of heavy metals in cultivated topsoil and grain, including correlations with human primary liver, lung and gastric cancer, in Anhui province, Eastern China. Sci. Total Environ. 470, 340, 2014.

5. LIU H., ZHANG Q., WANG Y., CAI Z., JINAG G. Occurrence of polychlorinated dibenzo- $p$-dioxins, dibenzofurans and biphenyls pollution in sediments from the Haihe River and Dagu Drainage River in Tianjin City, China. Chemosphere. 68, 1772, 2007.

6. WANG C., JI J., YANG Z., CHEN L., BROWNE P., YU R. Effects of Soil Properties on the Transfer of Cadmium from Soil to Wheat in the Yangtze River Delta Region, China - a Typical Industry - Agriculture Transition Area. Biol Trace Elem Res. 148, 264, 2012.

7. ZHAO F., MA Y., ZHU Y., TANG Z., MCGRATH S. Soil contamination in China: current status and mitigation strategies. Environ Sci Technol. 49, 750, 2015

8. WU J., ZENG R., REN T. Geochemistry characteristics and evaluation of the pollution extent of arsenic in wastewater irrigated soil in the North of Tianjin City. Front Earth Sci China. 2, 58, 2008.

9. ZENG, X., TWARDOWSKA I., WEI S., SUN L., WANG J., ZHU J., CAI J. Removal of trace metals and improvement of dredged sediment dewaterability by bioleaching combined with Fenton-like reaction. J Hazard Mater. 288, 51, 2015.
10. ZENG X., WANG Z., WANG J., GUO J., CHEN X., ZHUANG J. Health risk assessment of heavy metals via dietary intake of wheat grown in Tianjin sewage irrigation area. Ecotoxicology. 1, 2015.

11. CHENG C., XU Z., MATHERS N. Soil carbon pools in adjacent natural and plantation forests of subtropical Australia. Soil Sci Soc Am J. 68, 282, 2004.

12. WANG C., YANG Z., YUAN X., BROWNE P., CHEN L., JI $\mathrm{J}$. The influences of soil properties on $\mathrm{Cu}$ and $\mathrm{Zn}$ availability in soil and their transfer to wheat (Triticum aestivum L.) in the Yangtze River delta region, China. Geoderma. 193, 131, 2013.

13. CUI Y., ZHU Y., ZHAI R., CHEN D., HUANG Y., QIU Y., LIANG, J. Transfer of metals from soil to vegetables in an area near a smelter in Nanning, China. Environ Int. 30, 785, 2004.

14. OLUWATOSIN G., ADEYOLANU O., DAUDA T., AKINBOLA G. Levels and geochemical fractions of $\mathrm{Cd}$, $\mathrm{Pb}$ and $\mathrm{Zn}$ in valley bottom soils of some urban cities in southwestern Nigeria. Afr J Biotechnol. 7, 19, 2008.

15. MAPANDA F., MANGWAYANA E., NYAMANGARA J., GILLER K. The effect of long-term irrigation using wastewater on heavy metal contents of soils under vegetables in Harare, Zimbabwe. Agric Ecosyst Environ. 107, 151, 2005.

16. NIGAM R., SRIVASTAVA S., PRAKASK S., SRIVASTAVA M. Cadmium mobilisation and plant availability - the impact of organic acids commonly exuded from roots. Plant Soil. 230, 107, 2001.

17. DU L., RINKLEBE J., VANDECASTEELE B., MEERS E., TACK F. Heavy metal mobility and availability in estuarine and riverine floodplain soils and sediments: a review. Sci. Total Environ. 407, 3972, 2009.

18. ZHAO K., LIU X., XU J., SELIM H. Heavy metal contaminations in a soil-rice system: identification of spatial dependence in relation to soil properties of paddy fields. $\mathrm{J}$ Hazard Mater. 181, 778, 2010.

19. ZENG F., ALI S., ZHANG H., OUYANG Y., QIU B., WU F., ZHANG G. The influence of $\mathrm{pH}$ and organic matter content in paddy soil on heavy metal availability and their uptake by rice plants. Environ pollut. 159, 84, 2011.

20. WANG Z., ZENG X., GENG M., CHEN C., CAI J., YU, X., ZHANG H. Health Risks of Heavy Metals Uptake by Crops Grown in a Sewage Irrigation Area in China. Polish J Environ Stud. 24, 1379, 2015.

21. ZHAO K., LIU X., ZHANG W., XU J., WANG F. Spatial dependence and bioavailability of metal fractions in paddy fields on metal concentrations in rice grain at a regional scale. J Soil Sediment. 11, 1165, 2011.

22. LI Y., WANG Y., GOU X., SU Y., WANG G. Risk assessment of heavy metals in soils and vegetables around non-ferrous metals mining and smelting sites, Baiyin, China. J Environ Sci. 18, 1124, 2006.

23. ZENG X., WEI S., SUN L., JACQUES D., TANG J., LIAN M., XU Z. Bioleaching of heavy metals from contaminated sediments by the Aspergillus niger strain SY1. J Soil Sediment. 15, 1029, 2015.

24. YANG H., LI Z., LU L., LONG J., LIANG Y. Cross-Species Extrapolation of Prediction Models for Cadmium Transfer from Soil to Corn Grain. Plos one. 8, 12, 2013.

25. HAKANSON L. An ecological risk index for aquatic pollution control. A sedimentological approach. Water Res. 14, 975, 1980.

26. ZHENG T., CHEN C. Environmental System Mathematics Model. Chinese Chemical Industry Press and Environmental Science Press 120, 2003 [In Chinese]. 